\title{
Terörizmle Mücadelede Yeni Bir Trend Olarak Terör Örgütleriyle Görüşme Tekniği: PKK/KCK Örneği
}

\author{
Emin GÜNEŞ•
}

Öz

Günümüz dünyasında, terör örgütleriyle mücadelede ön plana çıkan müzakere teknikleri ile birlikte müzakere süreçleri, uzun yıllar devam eden öğrenme süreçleri olarak kabul edilmektedirler. Her örgüt kendi içerisinde ayrı karakteristik özellikler taşımakla birlikte, özellikle etnik/bölücü terör örgütleriyle gerçekleştirilen müzakerelerden çıkarılacak sonuçlar atılacak yeni adımlar açısından yol gösterici niteliktedirler. Bu çalışmada müzakere teknikleri SWOT (Strenghts-güçlü yönleri, Weaknesses-zayıf yönleri, Oppurtunities-fırsatlar, Threats-tehditler) analizi çerçevesinde incelenmiş ve neden müzakere tekniklerine müracaat edilmelidir sorusunun cevabı SWOT tablosu ile verilmiştir. Araştırma yöntemi, Türkiye'de gerçekleşen çözüm süreçlerinin mukayeseli analizine ve özellikle IRA ve ETA örnekleriyle karșılaştırmalı analizine dayanmaktadır. Kiminle, ne zaman, nasıl müzakere edilmeli, sorularının yanıtları karşılaştırmalı analize dayalı olarak verilmiştir. Çalışmanın sonuçları, güçlü bir devlet adamı öncülügündeki müzakerenin; aktörlerinin farklılaştırılması, toplumsal alt yapının sağlanması ve toplumun fikrî olarak bu düşünceye hazırlanması, muhalefetin desteğinin sağlanması halinde başarıya ulaşma ihtimalinin daha yüksek olduğunu göstermektedir. Bu çalışma, doğru ve yanlışlarıyla var olan bir sürecin akademik anlamda incelenerek, daha sonra atılacak adımların daha sağlam atılmasına yol gösterdiği için önem arz etmektedir.

Anahtar Kelimeler: Terörle Mücadelede Müzakere, Demokratik Açılım, Çözüm Süreci, KCK, SWOT Analizi.

\section{Negotiations with Terrorist Organizations As A New Trend in the Fight Against Terrorism: Case of PKK/KCK}

\begin{abstract}
In today's world, negotiation techniques have become to the popular in the fight against terrorist organizations. The negotiation processes are accepted as long-term learning processes, in the literature. Although each organization has distinct characteristics, the results to be drawn from the negotiations with the ethnic/separatist terrorist organizations are guiding the new steps.
\end{abstract}

Özgün Araștırma Makalesi (Original Research Article)

Geliş/Received: 11.12 .2018

Kabul/Accepted: 24.06 .2019

DOI: http://dx.doi.org/10.17336/igusbd.492732

• Dr., Hukukçu, (Gazi Üniversitesi, Siyaset Sosyal Bilimler), Ankara, Türkiye,

E-posta: dr.emingunes@gmail.com, eminacademic@gmail.com ORCID ID https://orcid.org/0000$\underline{0002-4796-0987}$ 
In this study, negotiation techniques were examined in the framework of SWOT analysis. Especially settlement process taking place with the IRA and ETA as a comparative sample process was analyzed. The results of the study show that of a powerful statesman-led negotiation; differentiation of the actors, the provision of social infrastructure and the preparation of this idea as the idea of the society, with the support of the opposition it is more likely to achieve success. This study is important in terms of examining an existing process in the academic sense, as the steps to be taken later are taken more firmly.

Keywords: Negotiation in Countering Terrorism, Democratic Opening, Solution Process, KCK, SWOT Analysis.

\section{Giriş}

Terör örgütleri ve terörizmle mücadele konuları ile ilgili akademik çalışmalar 11 Eylül 2001 saldırıları sonrasında hız kazanmakla birlikte, terör örgütlerinin tarihi M.Ö 7366 yıllarında faaliyet gösteren Sisarilere kadar uzanmaktadır (Caşın, 2007, s. 228). Terör örgütleri, son yüz yıllık süreçte faaliyet gösterdikleri ülkeler için ciddi sorunlar doğurmakla beraber 11 Eylül sonrasında "küresel terör" ve küresel teröre karşı küresel mücadele konsepti ile dünyanın gündemine oturmuşlardır. Bu bağlamda ilk dönemler teröristleri akıl hastaları olarak gören ve teröristlerin öldürülmeleri ile terör sorununun biteceğini düşünen yaklaşım gelișerek, stratejik eylem olarak görülen terör eylemlerini doğuran nedenlerin ortaya çıkarılması ve buna bağlı olarak önleyici tedbirlerin alınmasına doğru gelişmiștir. Evrimini terör örgütleriyle müzakere/görüşme şeklinde tamamlayan bu süreç Türkiye'de $\mathrm{PKK} / \mathrm{KCK}$ terör örgütüne karşı uygulanmaya çalışılmıştır. Çalışmada terör örgütü PKK'nın KCK'ya evrilmesi sonrasında gelişen Demokratik Açılım (2009-2011) ve Çözüm Süreci (2013-2015) çalışmaları dünyadaki benzer örnekleri ile karşılaştırılarak KCK ekseninde incelenmiş, bu sürecin doğruları ve yanlışları ortaya çıkarılmaya çalışılmıștır. Zira özellikle etnik terör ile mücadelede çözüm için geliştirilen görüşme tekniği, konunun akademik anlamdaki mimarı sayılabilecek bir akademisyen olan Guelke (2008, s. 65) tarafından uzlaşmadan anlaşmaya varan bir "öğrenme süreci” olarak nitelendirilmektedir. Demokratik Açılım ve Çözüm Süreçleri de bu bağlamda değerlendirilmeli, toplumsal bir yara haline gelen bu problemin bir anda çözüme kavuşması beklenmemelidir. Diğer taraftan bu süreçlerden çıarılacak dersler gelecek süreçlere rehberlik edebilecek nitelikte olduklarından çalışmada süreçler sadece tarihsel perspektiften ele alınmayıp, stratejik öneri sunabilecek nitelikte SWOT analizi mantığı ile ele aldığından önem arz etmektedir.

\section{PKK'nın Dönüşümü: KCK}

1973'te "Apocular" olarak bilinen terör örgütü tarihsel süreç içerisinde PKK (1978-2002), KADEK (2002-2003), KONGRA-GEL (2003-2005), KKK (2005-2007), Kürdistan Halklar Topluluğu (KCK, 2007-...) yapılarına evrilerek değişmiștir. Bu yapılardan her birisi örgütsel sistematik açısından birbirlerinden farklı oluşumlar olup, yapısal anlamda başlı başına ayrı bir inceleme konusunu olușturmaktadırlar. Klasik sol örgütlenmelerde var olan parti-cephe-ordu yapılanması ile doğan PKK terör örgütünün bu yapılanmanın ötesinde aşağıdan yukarıya meclisleşme pratiğini öngören KCK çatı kurumsallaşması, pratik ve teorik anlamda uzun yıllar terörle mücadele etmiş bir devlet olarak Türkiye Cumhuriyeti'nin ilk defa karşı karşıya kaldığı bir oluşumdur. 2007 yılından 
itibaren kurulan bu yapılanmanın temel kodları "KCK Sözleşmesi” ${ }^{1}$ adı verilen, bir nevi örgütün anayasası hüviyetindeki metinde yer almaktadır.

KCK yapısı ve örgütlenme sistematiği başlı başına bir çalışma konusudur. $\mathrm{Bu}$ makalede çözüm süreçlerindeki rolünün anlaşılması bakımından KCK ile ilgili özet bilgi verilmiştir. KCK sözleșmesi lafzi olarak her ne kadar devlet kurma amacında olmadığını iddia eden "demokratik toplumcu-konfederal bir sistem" olarak kendini tanımlasa dahi bir hukukçu gözü ile sözleşme, basitçe, maddeleri bazında incelendiğinde dahi devletin temel erkleri olan yasama-yürütme-yargı organlarını barındıran, üyelerini "yurttaş (vatandaş)" olarak adlandıran ve yurttaşlara temel hak ve özgürlükler bahşeden aynı zamanda mükellefiyetler yükleyen, vergi, askerlik sistemi ve güvenlik gibi devletin temel fonksiyonlarını üstlenen yapıların oluşturulduğu amblem ve bayrağı olan bu sistemin aslında paralel bir devlet yapılanması olduğu anlaşılacaktır. David Held'in (2006) demokratik özerklik ve Bookchin'in (1990) konfederalizm tezinden esinlenen Öcalan, KCK'nın ana fikri olan demokratik konfederalizmi, Kürtler ve hatta tüm Ortadoğu halklarının barışı için tek çözüm yolu olarak nitelendirmekte ve söylem bazında demokrasiyi ön plana çıkartmaktadır (Öcalan, 2015a, s. 28). Bununla beraber örgütün amaç ve eylemleri Öcalan'ın söylemleriyle birlikte bütüncül bir bakış açısıyla değerlendirildiğinde KCK yapılanması ile varılmak istenen nihai amacın Irak, İran, Suriye ve Türkiye topraklarında kurulacak "Bağımsız Birleşik Kürdistan" olduğu ortaya çıkmaktadır.

KCK'nın örgütsel yapısı ve sözleșmesinin derinlemesine incelenmesi makalenin hacmini oldukça genişletecektir ancak KCK'nın çözüm süreçlerindeki rolünün ortaya konulması için yukarıda özetin özeti mahiyetindeki bilgilendirmenin yanı sıra kısaca iki hususa değinmek gerekmektedir. İlk olarak Yargıtay 9. Ceza Dairesi KCK'nın mahiyetiyle ilgili olarak 2011/10371 ve 2014/5275 esas numaralı iki kararında PKK ile KCK'nın organik bağını tartışmış ve PKK'nın KCK'ya organik olarak bağlı olduğu, KCK'nın PKK'nın amaç ve stratejisini benimseyen silahlı unsurları da içerisine alan bir çatı yapılanmayı oluşturduğu sonucuna varmıștır. İkincisi; sözleșmenin 11. Maddesinde "kurucu ve önder" olarak Öcalan'a işaret edilmekte, temel stratejilerin belirlenmesinde son karar alma mercii ve alınan kararların onay makamı olduğu açıkça belirtilmektedir. KCK'nın çözüm süreci içerisindeki rolü bu mahiyeti göz önünde bulundurularak değerlendirilmelidir.

Son tahlilde; özgün yapılanma olarak bünyesinde PKK'yı diğer taraftan ise silahlı unsurları barındıran çatı yapı olan KCK oluşumu neticesinde legal Kürt siyaseti üzerinde hâkimiyet kuran örgüt, bir dönem Kürt siyasetini vesayeti altına alarak siyasetin ana çizgilerinin belirleyicisi haline gelmiştir (Güneş, 2018). Çözüm süreçlerinde de vesayet hâkimiyetin izleri belirgin olmakla beraber sürecin kayıplarının kazanımlarından daha fazla olmasının ana nedeni bu hâkimiyettir.

\section{SWOT Analizi Çerçevesinde Terör Örgütleriyle Müzakere Süreçleri}

Terör ve terörizmle mücadele; terörist ile askeri-polisiye tedbirler ile mücadeleden bu tedbirlerin yanında terörü doğuran sosyal koşulların ortadan kaldırılması ve demokratik adımların atılması ile müzakere tekniklerinin kullanılmasına yönelik tarihsel bir seyir söz konusudur. Bal'ın (2006, s. 35) ifadesiyle terörle yani "stratejik eylem" ile mücadeleden terörizm yani "stratejik söylem" ile mücadeleye doğru bir dönüșüm gerçekleşmektedir. 1968-2006 yılları arasında doğan 648 terör örgütüne ait verilerin incelendiği bir araștırmada; 244 örgütün halen aktif olduğu ve 136 örgütün ise

\footnotetext{
${ }^{1}$ Sözleşme metni için bkz. (Güler, 2010, s. 197-228); http://www.sosyalistforum.net/politikgundem/17456-koma ciwakenkurdistan sozlesmesi.html
} 
isim değiştirerek veya bölünerek faaliyetlerine devam ettiği, kalan 268 örgütten 27 tanesi (\%10) örgütlerin amaçlarına ulaşması, 20 tanesinin (\%7) askeri tedbirler ile 107 tanesinin (\%40) polisiye tedbirler ile 114 tanesinin (\%43) ise müzakere ve barıș anlașmalarını da kapsayan siyasal tedbirler ile yok edildiği bulgusuna ulaşılmıștır (Jones \& Libicki, 2008, s. 18-21). Her ne kadar her bir terör örgütü ve her müzakere örneği (ETA, IRA, LTTE, KCK) birbirinden bağımsız ve farklı bileşenlere sahip olsa dahi bu örnekler mücadele bakımından genel konseptin çizilmesinde yol gösterici olabilecek niteliktedirler. $\mathrm{Bu}$ bağlamda müzakere tekniğinin terörizmle mücadeledeki önemi ortadadır. Tarihsel bir analoji olarak; tam anlamıyla bir terör örgütü kabul edilemeyecek ancak devlete karșı isyan bağlamında benzer özellikler taşıan 16-18. yüzyıllardaki "eşkıya" yapıları ile mücadelede eden Osmanlı Devleti bu hoşnutsuz grupların yeniden kazanılması veya yok edilmesi açısından müzakere tekniği kullanmıştır (Barkey, 2011). Eşkıya oluşumlarına nazaran daha farklı ve karmaşık yapılar olan terör örgütleri ile yürütülecek müzakere süreçlerindeki başarı önceden düşünülmüş stratejik adımlara bağlıdır. SWOT tekniği bu adımların tespitinde yön gösterici olabilecek adımların tespitinde kullanılabilecek bir analiz yöntemidir.

İngilizcedeki "strenghts (güçlü yönler)", "weakness (zayıf yönler)”, “opportunities (firsatlar), "threats (tehditler)" kelimelerin baș harflerinden oluşan SWOT analizi yöntemi genel kanının aksine sadece ticari işletmelerin yahut kurumların verimliliğini arttırmak ve karar verme süreçlerine yardımcı olmak için kullanılmamaktadır. SWOT analizi tekniği var olan bir problemi tanımlayıp ona uygun çözüm önerileri ve stratejiler geliştirmek için analitik düşünce sistematiği geliştiren bir yöntemdir (Kurtilla, Mauno, Kangas, \& Kajanus, 2000). Bu bağlamda terörle müzakere yönteminin başarısı; müzakerenin belirli bir stratejik konsepte bağlı olmasıyla doğrudan ilgili olup, bu konseptin geliștirilmesinde SWOT analizi önemli bir etkiye sahiptir. Terör örgütleriyle mücadelede müzakere tekniği konusundaki bilimsel literatürün analizi gerçekleştirilmiştir. Bu çalışmanın neticesinde terör örgütleriyle müzakerenin güçlü-zayıf yönleri, fırsatları ve ortaya çıkarttığı tehditler aşağıdaki SWOT tablosunda yer almaktadır.

\begin{tabular}{|c|c|}
\hline MÜZAKERENİN GÜÇLÜ YÖNLERİ & MÜZAKERİNİN ZAYIF YÖNLERİ \\
\hline $\begin{array}{l}\text { 1.Terör örgütünün yok edilmesine ve toplumsal } \\
\text { barışın sağlanmasına hizmet eder (Khan, 2013, s. } \\
\text { 64). } \\
\text { 2.Terör örgütünü illegal alandan çıkartıp, örgütün } \\
\text { fikirlerini siyasi alanda legal olarak savunma } \\
\text { imkânı sağlar (Byman, 2006, s. 412). } \\
\text { 3.Yasal siyasi kanalların açılmasına, örgütlerin } \\
\text { legal siyasi alana kaymasına neden olur (Cronin, } \\
\text { 2006, s. 25) } \\
\text { 4.Devletin, terör örgütünün içyapısını öğrenmesini } \\
\text { sağlar. Devlet; örgütün hedefini, ideolojisini ve } \\
\text { istismar ettiği mağduriyet konularını daha } \\
\text { yakından tanır (Richardson, 2006, s. 258). } \\
\text { 5.Örgütün gizli ajandasını ortaya çıartır (Cronin, } \\
\text { 2010, s. 3) } \\
\text { 6.Örgüt üyesi veya sempatizanı seviyesindeki } \\
\text { radikallerin yalnızlaşmasına, llımlı görüşlere } \\
\text { sahip olanların ise örgüt konusundaki fikirleri } \\
\text { sorgulamalarına neden olabilir (Clark, 1990, s. } \\
\text { 2). } \\
\text { 7.İletişim kuran taraflar karşılıklı olarak } \\
\text { birbirlerini etkileyeceklerdir bu durum Vamık } \\
\text { Volkan tarafından "konuştuğunu öldüremezsin" }\end{array}$ & $\begin{array}{l}\text { 1.Müzakere süreci, terör örgütü tarafından } \\
\text { yeniden organize olup silahlanma } \\
\text { kapasitesini arttırma süreci olarak } \\
\text { değerlendirilir (Byman, 2006, s. 408). } \\
\text { 2.Örgütle görüşmek devletin saygınlığını } \\
\text { azaltır, terör örgütleri bakımından bir } \\
\text { kazanım olarak değerlendirilir aynı } \\
\text { zamanda toplumsal önyargının ve kinin } \\
\text { oluşmasına neden olur (Pillar, 2001, s. } \\
\text { 142). } \\
\text { 3.Devletin müzakere sürecine girmesi, terör } \\
\text { örgütünün statü kazanmasına neden olur } \\
\text { (Steinberg, 2015, s. 94). } \\
\text { 4.Siyasi değişimi barıșçıl yollarla sağlamaya } \\
\text { çalıșanların bir şey elde edemeyeceği } \\
\text { düşüncesinin dogmasına neden olur } \\
\text { (Neumann, 2007, s. 128). } \\
\text { 5. Müttefik olunan bir ülkede de faaliyet } \\
\text { gösteren bir terör örgütü ile masaya } \\
\text { oturmak uluslararası ilișkilere zarar } \\
\text { verecektir (Byman, 2006, s. 408). } \\
\text { 6.Terör örgütleri listesinde yer alan bir } \\
\text { örgüt ile masaya oturmak, bu listede yer }\end{array}$ \\
\hline
\end{tabular}


şeklinde kavramsallaştırılmıștır (Erdoğan İ. , 2013, s. 358).

8.Örgüt üyesi, sempatizanı yahut tarafgirlerinin akıllarında sorunun, terör yöntemleri dışındaki bir formülle çözülebileceği fikri doğurur.

\section{MÜZAKERENİN YARATACAĞI FIRSATLAR}

1.Müzakere sürecinde terör örgütünün kendi içerisinde gruplara bölünmesi ve radikal grubun daha kolay yok edilmesi mümkün olabilir (Cronin, 2006, s. 25)

2.Görüşmeler örgüt içerisindeki muhalif grupların şiddetten vazgeçmelerini sağlayabilir. Diğer taraftan örgüt, taraftarlarında var olan sempatisini kaybetmemek için șiddetti durdurabilir (Byman, 2006, s. 405).

3.Analitik bir araştırmanın bulgularına göre görüşme esnasında örgütler eylemlerini ve şiddet katsayılarını düşürmektedirler (Cronin, 2009, s. 41) almanın olușturduğu olumsuz havayı bertaraf edecektir (Byman, 2006, s. 407).

\section{MÜZAKERENIN OLUSSTURACAĞI} TEHDITLER

1.Müzakereler, kamuoyunda şiddet kullanılmadan bir sonuca ulaşılamaz imajı oluşturabilir (Byman, 2006, s. 406).

2. Müzakereler esnasında örgütün ikiye ayrılması halinde, örgütten ayrılan grubun daha radikal bir grup olması ihtimali yüksektir ki bu grup daha vahşice eylemler yapabilir (Cronin, 2006, s. 26).

3. Demokratik rejimlerde terör örgütleriyle görüşmek politik intihar olabilir (Cronin, 2010, s. 2).

4.Örgüt, müzakere sürecini şiddet kapasitesini arttırmak için geçiş dönemi olarak kullanabilir (Byman, 2006, s. 406)

Analiz tablosunda net bir şekilde görüldüğü gibi müzakerenin güçlü yanları ve doğuracağı firsatlar, zayıf yönleri ve olușturacağı tehditlere nazaran ön plana çıkmaktadır. Son 30 yıllık süreçte bir mücadele tekniği olarak kullanılan ve örgütler açısından "sonun başlangıcı" olarak nitelendirilen bu yöntemin; kiminle, ne zaman, ne şekilde müzakere sorularına SWOT analizi çerçevesinde verilecek analitik yanıtlar bağlamında kullanılması gerekmektedir (Jones O. E., 2017). Öyleyse müzakerenin bir yöntem olarak kullanılabileceği ki IRA, ETA, PLO gibi örgütlerde olumlu sonuç verdiği gerçeği göz önüne alındığında bu noktadan sonra analitik düzlemde kiminle, ne zaman, nasıl müzakere edilmedi sorularının cevabı aranmalıdır.

\subsection{Müzakere: Kiminle, Ne Zaman, Nasıl?}

Sosyo-politik yahut ekonomik nedenlerden kaynaklanan ve uzun yıllar süren çatışmaların müzakerelerin başlaması ile sorunun doğrudan çözüleceğini ve çatışmaların son bulacağını düşünmek çok iyimser bir bakıș açısı olur ki bu durumun reel politikte bir karşıllğı bulunmamaktadır (Crenshaw, Wilkinson, Alterman, \& Schaffer, 1999). Literatürde terör örgütleriyle müzakere konusunda "erkli-erksiz, rasyonel-irrasyonel, özerk-bağımlı" (Erdoğan, 2013, s. 360-364; Zartman, 2003) gibi sınıflandırmalar yapılıp, görüşmelerin erksiz, rasyonel, bağımsız örgütlerle gerçekleştirilmesi halinde verim alınabileceği sonucuna varılmıştır. Bu makalenin odak noktası müzakerenin hangi örgütlerle yapılacağından ziyade müzakere kararı alındıktan sonra örgüt içerisinde ve dışında kimlerle görüşme yapılması gerektiğinin ortaya çıkarılması olduğundan, literatürde var olan bu sınıflandırmaya değinmeden doğrudan kiminle müzakere edilmeli sorusunun cevabı aranmaktadır.

Müzakere sürecinde taraflardan birisi devlet diğeri ise terör örgütüdür. Sürecin doğası gereği devletler, terör örgütleriyle masaya oturmak durumundadırlar. Görüșmeler, hükümetlerin önceden planladığı süreçler olarak sadece örgüt yöneticileri ile yürütülmemelidir (Cronin, 2006, s. 26-27). Bunun yanı sıra toplumsal etki 
oluşturabilecek her türlü sivil toplum kuruluşları, dernekler, vakıflar, konunun tarafı olabilecek siyasi partiler ve kanaat önderleri ile de temasa geçilmeli ve sürece bir şekilde dâhil edilmelidirler. İspanya'nın ETA ile mücadelesindeki başarısının altında yatan ana unsur Bask bölgesinin bağımsızlığını savunan siyasi partilerden kanaat önderlerine tüm toplumsal yapıyı müzakere sürecine dâhil edebilmesidir (Özçer, 2006). IRA ile Birleşik Krallık hükümetlerinin bir dönemki görüşmelerinde din adamları arabuluculuk görevi üstlenmeleri ve Sinn Fein'in yanı sıra diğer siyasi partilerinde sürece katılımlarını sağlama çabaları müzakereleri olumlu etkilemiştir (Cronin, 2009, s. 45). Müzakere süreçlerinin olumlu sonlandığı örneklerin hemen hemen hepsinde müzakere masasında, terör örgütü yöneticilerinin yanı sıra bir şekilde diğer toplumsal aktörlerde yer almaktadırlar.

Terörle mücadelede kullanılacak yöntemler literatürde; askeri polisiye tedbirlerin alınması, ceza adalet sistemindeki değişiklikler, önleyici tedbirlerin arttırılması ve örgütlerle müzakere şeklinde sıralanmakla beraber müzakerenin ne zaman yapılacağı ile ilgili bir kesinlik söz konusu değildir. 1995-2001 yılları arasında gerçekleşen çatışma hareketlerini ve neticelerini, istatistiksel olarak analize tabi tutan bir çalışmada; en verimli müzakere zamanın çatışmaların ilk başladığı zamanlar olduğu fakat bu dönemlerde devletlerin güç kullanmak suretiyle sorunun çözülebileceğini düşündüklerinden müzakereye yanaşmadıkları bulgusuna ulaşılmıştır. Aksi halde zamanla güçlenen örgütlerin sonraki dönemlerdeki müzakere süreçlerindeki taleplerinin farklılaşacağı ve koz olarak kullanabilecekleri argümanların sayısının artabileceği ileri sürülmektedir (Bapat, 2005, s. 713-714). Terör örgütlerinin en güçsüz olduğu dönemin müzakere sürecinin başlangıcı olarak seçilmesi devletleri elde etmek istediği sonuca daha kolay ulaștıracaktır (Crenshaw, Wilkinson , Alterman, \& Schaffer, 1999, s. 1). Örgütün en zayıf olduğu anın seçilmesi konusunda istihbarat yetkililerine önemli görevler düşmektedir. Yapılacak istihbari çalışmalar neticesinde örgütün üye sayısı, araç gereç durumu, eylem potansiyeli gibi kritik hususların risk analizleri yapıldıktan sonra müzakere süreçlerinin başlatılması, sürecin başarısı bakımından oldukça önemlidir. Byman (2006, s. 409)'a göre örgütün, mücadeleyi silahla kazanamayacağını düșündüğü bir anda masaya oturtulması halinde önkoşulsuz bir müzakere süreci başlayacaktır. IRA örneğinde 1990'lı yıllardan sonra kazanılan başarıların altında Britanya'nın IRA'yı silahlı mücadele ile temizleyemeyeceği, IRA'nın da silahlı mücadele ile istediği kazanımları elde edemeyeceği kanaatine varmış olması yatmaktadır (Coackley, 2003, s. 34)

Doğru aktörler ve doğru zamanlama sonrasında sürecin nasıl yönetileceği sorunsalı ile karşılaşılmaktadır. Zartman'ın (2003, s. 449) deyimiyle devlet görevlisi “çok almak için az vermek" vazifesini üstlenmektedir. Müzakere süreci; sabır gerektiren, uzun soluklu, kanaviçe gibi işlenmesi gereken bir süreç olmakla beraber bu süre zarfinda istihbari destek hayati önem arz etmektedir (Cronin, 2010, s. 4). Görüşmelerin amacı teröristlerin taleplerini müzakere etmenin ötesinde sorunun demokratik yollarla çözülebileceğinin kamuoyu nezdinde kabul edilebilirlik kazanmasını sağlamaktır. Bu sayede barıșçl çözümün mümkün olduğunu gören toplumlarda, terör örgütlerine verilen destek azalacak ve teröre müzahir olan kesimlerde dahi sorunun barışçll yollarla çözümünün mümkün olduğu fikri oluşturulacaktır (Crenshaw, Wilkinson, Alterman, \& Schaffer, 1999, s. 1). Bu tür bir müzakere tekniği örgütün kendi içerisinde çözüm yanlıları ve silahlı mücadele taraftarları olarak bölünmesine neden olabilecektir. Bölünme neticesinde müzakere sürecinde aynı zamanda askeri-polisiye tedbirlerle örgütle mücadele eden devletlerin, bu mücadeleyi kazanma oranları artmaktadır. Tamil Kaplanları (LTTE) ile mücadele eden Sri Lanka hükümetinin başarısız olmasının bir nedeni de müzakere süreciyle birlikte askeri-polisiye tedbirleri eş zamanlı olarak alamamış olmasıdır. Bir yandan devletle görüşmeler sürdüren örgüt diğer yandan terör 
eylemlerini devam ettirmiştir (Crenshaw, Wilkinson, Alterman, \& Schaffer, 1999, s. 1011).

Müzakerelerde başarının bir diğer anahtarı ise hükümet tarafından yürütülen bu sürece ciddi bir toplumsal desteğin sağlanması ve muhalefetinde sürece zarar verecek açıklamalarda bulunmaktan kaçınmasıdır (Whitfield, 2015, s. 13). Zira bu görüşmelerde elde edilecek olan başarı tek başına hükümetin değil tüm devletin başarısı sayılmalıdır. Başarıyı sağlayabilmek ve toplumsal muhalefeti bertaraf edebilmek için görüşmelerin kamuoyundan gizli yapılmaya başlaması ve belirli bir yol kat edildikten sonra açık görüşmelere geçilmesi doğaldır. Bu nedenledir ki terör örgütüyle ilk temasın daha alt rütbeli kamu görevlileri aracılığıyla kurulması daha sağlıklı olacaktır çünkü bu sayede ilk görüşmelerin verimsiz olması halinde oluşacak olan olumsuz hava daha kolay bertaraf edilebilecektir. Bu yöntemin etkinliğini Byman (2006, s. 405), IRA üzerinden açılklamakta ve Birleşik Krallığın IRA ile müzakerelerini 1972 yllında alt rütbeli istihbarat görevlileriyle bașlattığını, bir dizi gizli görüșme sonrasında açık müzakerelere geçildiğini belirtmektedir. Franco diktatörlügünden sonra demokrasiye geçen İspanya, ETA ile görüşmelerine kamuoyundan gizli olarak 70'li yılların ortalarına başlamış ve süreç belirli bir olgunluğa eriştikten sonra ETA ile görüşüldüğü kamuoyuna açıklanmıştır (MartínezHerrera, 2008, s. 6).

Terör örgütleriyle müzakere konusunda genel geçer doğruların bulunması mümkün olmamakla beraber şimdiye kadar gerçekleşen müzakere süreçlerinin akademik anlamdaki çıktıları yukarıda özetlenmiştir. Bir sonraki alt başlıkta ise karşılaștırmalı analize imkân tanıması açısından Demokratik Açılım ve Çözüm Süreçleri incelenmiştir.

\subsection{Demokratik Açılım Süreci}

PKK ile gerek devlet adına istihbarat biriminin sürdürdüğü görüşmeler, gerekse siyasal alanda Hükümetler adına aracıların yürüttügü ilişkilerde temel yaklaşım Kürt sorununun çözümü odağında gelişmiştir. Kürt sorununun çözümü konusu her ne kadar PKK endeksli bir olgu olmasa da, bu sorunun ortaya çıkardığı problemlerden birisi olması sebebiyle PKK terörünün şiddetinin önemi ve ortadan kaldırılması yadsınamaz bir gereklilik olarak ele alınmıştır. Bu bağlamda 1990'lardan itibaren başlayan görüşmelere genel bir kavram olarak "çözüm süreçleri" denilebilir (Çandar, 2011). PKK'nın siyasallaşması tartışmalarıyla 1990’lı yıllarda gündeme gelen "Hükümet-PKK Görüşmeleri" konusu aslında 1988 yllındaki gayri resmi görüşme girişimleriyle başlamıştır (Güller, 2015, s. 25). 1990’lı yıllardan itibaren gerçekleştirilen bir dizi görüşme girișiminden sadece Demokratik Açlım ve Çözüm Süreçlerine odaklanılacaktır.

Demokratik Açılım Süreci olarak bilinen ve Kürt Sorununun çözümü adına belirli niyet beyanlarını ve amaçları hayata geçirmeyi hedefleyen projenin temelleri, Başbakan Erdoğan tarafından 2005 yılında Diyarbakır mitinginde ortaya konulmuş ve yaklaşık dört yıllık bir hazırlık süreci neticesinde şekillenmiştir, AK Parti Hükümeti Kürt Sorunu odağındaki bu projeyi özünde demokrasi bağlamındaki sorunlara bağlayarak daha kapsamlı bir form haline getirmiş ve retoriğin farklı kesimlerde olumsuz etkilere yol açmasından kaçınmıştır (Akyürek, 2011, s. 17-20). Demokratik Açılım sürecinin hazırlık aşaması Öcalan-Taner (dönemin MİT Başkanı) görüşmeleri olarak nitelendirilirken, açılımın fiili başlangıcı ise 2009 yılındaki Oslo görüşmeleridir. Oslo görüşmeleri, belirli bir olgunlaşmayı sağladıktan sonra süreç içerisinde; devlet yetkilileri tarafından yerel Kürtçe isimler kullanılmış ve Kuzey Irak için "Kürdistan" nitelendirmesi yapılmıș, akademisyenler ve aydınlardan oluşan bir grup ile Kürt sorununa çözüm çerçevesinde çalıştay düzenlenmiş, iktidar ve BDP'li yetkililer arasında görüşmeler düzenlenmiş, 2009 yılı Ağustos ayında İçişleri Bakanlığı bünyesinde güvenlik bürokratları, akademisyenler ve siyasilerden oluşan bir heyetin teşkil edilmesi ve Mahmur Kampının boşaltılması için 
proje hazırlanmış, Öcalan'ın kırsaldan eve dönüş talimatları kapsamında 34 kişi Habur'dan Türkiye'ye giriş yapmıștır (CNNTürk, 2016).

$\mathrm{Bu}$ süreçte devlet yetkilileri, doğru bir strateji ile sosyo-ekonomik ve politik boyutlarıyla sorunu ele almış ve gerekli adımları atmıştır. Terör örgütü PKK/KCK ise bu gelişmeleri, çözümsüzlük girdabına sürüklemek suretiyle suiistimal etmiștir. Nitekim KCK yöneticisi olan Murat Karayılan, süreçle ilgili olarak Hasan Cemal'e verdiği röportajda hiyerarşik bir merhaleden bahsetmektedir. Görüşme yapılması gerekenleri hiyerarşik olarak "Öcalan, Kandil ve seçilmiş irade, akil adamlar" olarak vurgulayan Karayılan, bu görüşme mercilerinin hiyerarşik olduğunu ve seçimlik olarak herhangi biriyle görüşülmesinin doğru olmadığını iddia etmektedir. Sonuç alınmak isteniyorsa Öcalan veya Kandil ile devletin müzakere etmesi gerektiğini vurgulamaktadır (Karayılan, Karayılan: Barıș Umudumuz Var- Kuzey Irak Notları, 2009).

KCK yönetiminin Açılım sürecinde özellikle Habur olayındaki tutumu aslında süreci sabote edici bir nitelik taşımaktadır. "Eve Dönüş" olarak kamuoyuna duyurulan Habur sürecinde bir yandan PKK'nın askeri klyafeti olarak tanımlanan leşkeri giyerek gelen örgüt üyeleri imajı, öte yandan otobüs üzerinde il il gezilmesi ve bu sürecin kitleselleşmesi, sürecin en kırılgan boyutu olan Türkiye'nin Batı'sındaki insanlar açısından çok olumsuz bir etki oluşturmuştur. Eve dönüş ifadesi özünde sivil hayata geçiş, örgütten kopuş anlamlarına geldiği açık bir durumken, PKK/KCK kimliğinin ve aidiyetinin en net ifadesi olacak şekilde leşkerli bir görüntü verilmesi "silahlı mücadelenin zaferi" olarak kamuoyuna yansıtılmıștır. Bu mesaj sadece Türkiye kamuoyuna değil, uluslararası kamuoyuna da mesajlar vermiştir. Uluslararası alanda PKK açısından bu imaj önemli bir kazanım, meșruiyet-muhataplık kapısı olarak görülmüștür (Çandar, 2011, s. 82). Her ne kadar şekli bir konu gibi görülse de leşkerlerin çıkartılmamasının arka planında önemli mesajlar bulunmaktadır. Kırsala katılan bir kişi öncelikle kimliğini ve üzerindeki elbiselerini teslim ettikten sonra kırsalda yer almaya başlamaktadır. Bu durum artık yeni bir kimlik inşasına girdiğini ve elbiseleriyle bunu tamamladığı yönünde psikolojik bir mesaj olarak nitelendirilebilir. Örgütten ayrılan kişi için aynı şekilde üzerindeki örgüt elbisesini çıkarması ve sivil hayata adapte olması onun normal kimliğe dönüşünü sağlamaktadır. PKK/KCK, Habur'da dönüş yapan üyelerinin elbiselerini çıkartmayarak "PKK kimliğinin" dağdan sahaya indiği ve önemli bir kazanım elde ettiği mesajını vermiștir.

Demokratik Açlım sürecinin gelişimini belirleyen en önemli hususlardan birisi, Öcalan'ın KCK Yönetimine ve Avrupa yapısına yönelik mektup yazma izninin verilmesi ve bu mektuplarda Öcalan'ın süreçte örgütün stratejisinin nasıl olacağını belirlemesidir. Bu mektuplarda Öcalan izlenecek yol haritasına dair kapsamlı değerlendirmeler yapmıştır. Özellikle doğrudan doğruya siyasi konular olan "Hakikatleri Araștırma Komisyonu, Yeni Anayasa Komisyonu" gibi konulara yer vermiştir. Öcalan bu konularda gerekli adımların atılmasının gerekliliğini vurgulamış ve bu adımların koordinasyonunu KCK yönetimine havale etmiştir. Bu noktada da siyasi iradenin DTP'de değil, Öcalan ve KCK'da olduğu aşikârdır (Güller, 2015, s. 86). Bu durumun doğal bir sonucu olarak seçilmiş siyasi iradenin müzakerelerde ön plana çıkması Öcalan ve Kandil tarafından güç kaybı olarak değerlendirilmekte ve bu iradenin daha görünür olması engellenmektedir. Demokratik Açılım süreci içerisinde Osman Baydemir'in silahların susması gerektiğiyle ilgili açıklamasından sonra belediyede görevli taşeron işçilerin hâkim olarak görev aldığı "KCK mahkemesinde" yargılanması bu görüşün haklılığını gösteren somut bir örnektir.

Demokratik Açlım sürecinin mimarı ve asli icracısı olan AK Parti Hükümetinin Açılım politikaları üç ana esasa dayanmaktadır. Bu esaslardan birincisi; süreç içerisinde üniter yapının varlığını koruyacak olması ve bu yapının değiștirilmesinin söz konusu olmadığıdır. İkinci esas ise Öcalan için getirilecek bir affın söz konusu olmayacağıdır. Son olarak Kürtçe, kültürel konular, demokratikleşme ve ekonomik sorunların çözümüne 
yönelik geliștirilecek politikalar çerçevesinde sürecin genişletileceği vurgulanmaktadır (AK Parti, 2010).

Demokratik Açılım sürecinde AK Parti'nin bu yaklaşımı karşısında Öcalan, KCK ve DTP (BDP)'nin yaklaşımı ise Öcalan tarafından ortaya konulan yol haritasına göre gelişmiștir. Öcalan'ın 2009 yılında ortaya koyduğu yol haritasında vurguladığı hususlar, AK Parti'nin genel çerçevesini çizdiği süreç yönetimi ile mukayese edildiğinde Demokratik Açılım sürecinin neden uzun vadede devam edemediği sorusunun cevabı anlaşılmaktadır. Zira çatışma yönetimi açısından bu iki yaklaşım arasında ciddi uçurumlar söz konusudur. Bu yol haritasında Öcalan, devletleşme amacı olmayan ancak devletin güdümünde ve içinde erimeyen toplumun demokratik iradesini yansitan demokratik konfederalizm bağlamında ele aldığı "Demokratik Ulus" çözümünü önermektedir (Öcalan, 2011, s. 65-71). Öcalan, süreç açısından kendisini vazgeçilmez görmekte ve kendi konumuyla ilgili iyileștirici adımlar atılmadan sürecin ilerleyemeyeceğini de vurgulamaktadır.

Öcalan'ın yol haritasında belirttiği hususlardan öne çıkan en önemli nokta klasik ulus-devlet anlayışının sona ermesi ile oluşacak olan, KCK sözleșmesinde öngörülen, konfederal çözüm modelidir. Öcalan, Bu modelin hayata geçirilebilmesi için devletin belirli adımları atması gerektiğini ifade etmiștir. Öcalan yol haritasında PKK vurgusunu silahlı yapı olarak göstermeye çalışmakta, KCK'yı ise "Sivil Toplum Örgütü" şeklinde nitelendirmektedir. Oysaki KCK'nın örgütlenmenin bütüncül yapısını oluşturduğu KCK sözleşmesinde açıkça ifade edilmiştir. Öcalan'ın bu ayrımı, kamuoyunda KCK imajını legalleștirmeye ve siyasallaştırmaya yönelik taktiksel bir adımdır.

Ayrıca dikkat çeken bir diğer nokta ise Öcalan'ın yol haritasında mevcut legal siyasi partiyi süreç yönetiminde hiç dile getirmemiş olmasıdır. Süreçte aktör olarak PKK (silahlı birim ifadesiyle), KCK (siyasal birim ifadesiyle) ve İmralı (kendi konumu) bileşenlerinin bir taraf olduğunu ifade eden Öcalan, süreç yönetiminde arabulucu olarak 3. Göz gerektiğini de işaret etmiştir. 3. Göz olarak (Yılmaz, 2012) AB ve ABD’yi vurgulayan Öcalan ayrıca AK Parti ve Devleti ise "diğer taraf" şeklinde görmektedir. AK Parti'nin Demokratik Açılım yaklaşımı ile Öcalan'ın yol haritası arasındaki büyük ölçüde söyleme ve pratiğe yönelik farklılıklar bulunmaktadır. Her iki taraf ta kendi kamuoyu açısından daha dikkatli bir dil kullanmasına rağmen, somut ortak noktaların azlığı ya da yokluğu öne çıkmaktadır. Tüm bu nedenlerle birlikte Demokratik açılım süreci Habur olayı ile ilk heyecanını ve dinamizmini kaybederken, 14 Temmuz 2011 tarihinde Silvan'da 12 askerin şehit edilmesi ve aynı gün Demokratik Toplum Kongresi'nin (DTK) "Demokratik Özerklik" ilanı, açlım sürecinin fiilen bitmesine yol açmıştır (Yılmaz, 2012, s. 11).

\section{3. Çözüm Süreci ve Heyet Görüşmeleri}

Demokratik Açılım sürecinin bitmesiyle birlikte kırsal alanda başlayan askeri operasyonlarla eş zamanlı olarak KCK yapısına karşı șehirlerde de operasyonlar düzenlenmiştir. Bu operasyon süreci, geçmișteki operasyonel süreçlerden farklı olarak kurumlar arası koordinasyon esasına bağlı kalacak şekilde yürütülmüş ve PKK/KCK gerek kırsal alanda gerekse KCK yapılanmasının Türkiye ayağında ciddi şekilde daralma yaşamıştır. KCK/TM sözcülerinin operasyonlara dâhil edilmesi yapının etki sahasını daraltmıştır. Diğer taraftan MìT krizinin patlak vermesi, Oslo görüşmelerinin sızdırılması ve Uludere hadisesinin gerçekleșmesi operasyonları yavaşlatmış sonrasında ise örgüt üyeleri yurt genelindeki cezaevlerinde açlık grevine başlamıştır. Bu eylem, 16 Kasım 2012'de örgüt lideri Öcalan'ın açıklamasıyla sona ermiştir. Bu açıklama sonrasında, ulusal basında Öcalan'ın imajının değiștiğini söylemek mümkündür. 1999'dan beri Öcalan hakkında kullanılan "terörist başı, bebek katili, terör örgütü lideri" gibi ifadelerin "İmralı" 
ifadesine ikame edildiği görülmektedir. Yeni çözüm sürecinin ön hazırlığı olarak değerlendirilebilecek bu aşamadan sonra İmralı heyet görüşmeleri başlamıştır.

3 Ocak 2013'te başlayan çözüm süreci heyet görüşmeleri 2015 yllına kadar devam etmiş, süreç ise fiilen 7 Haziran seçimlerinden sonra ortaya çıkan siyasi tablo ve KCK'nın yeniden eylemlere bașlamasıyla sona ermiștir. Bu zaman aralığında Öcalan ile HDP'li vekillerden, MiT ve KDGM'den yetkililerin katıldığı çok sayıda heyet görüşmesi gerçekleşmiştir. Heyet görüşmelerinde bu süreçten itibaren dikkat çeken temel nokta çözüm sürecine ilişkin konuların çok az konuşulmasıdır. Görüşmelerde daha çok KCK yapısı üzerindeki revizyonlar, DTK'nın misyonu ve işlevi, HDK'nın seçimlerde izleyeceği strateji, örgüt yönetiminde kimlerin yer alması gerektiği konuları değerlendirilmiştir. Çözüm sürecine ilişkin konularda ise daha çok Öcalan'ın sürecin ilerlemediği, tıkanmalar yașandığı ve bunun sorumlusunun AK Parti olduğu yönündeki iddiaları öne çıkmıştır (Güller, 2015).

Heyet görüşmelerinin 2013'ün son aylarından 2014 Mart ayında gerçekleștirilen yerel seçimlere kadarki aşamalarında yoğun şekilde yerel yönetici adaylarının kimler olacağı tartışılmıştır. Tüm yerel yönetim adayları Öcalan'a aktarılarak onayı istenmiştir. Heyet görüşmeleri yerel seçimler sonrasında sürecin durağanlaşmasına bağlı olarak çözüm süreci ekseninden avukat görüşmeleri formuna dönüşmeye başlamıştır. $\mathrm{Bu}$ noktadan itibaren Öcalan taleplerinin yerine getirilmemesi halinde süreçten çekileceği şeklindeki ifadelerini sıklaştırmaya başlamış ve çatışmanın yeniden devreye gireceğini vurgulamıştır (Öcalan, 2015b, s. 130-175). Bu şartlar altında çözüm süreci heyet görüşmeleri odağında ilerlerken, heyet görüşmelerinde ise çözüm sürecinden çok örgütsel konuların konuşulması, çözüm sürecinin pratikleşmesini ortadan kaldıran en önemli sorunlardan birisi olmuştur.

2014 yılında çözüm süreci çıkış noktasından farklı bir kulvardaki tartışmalara doğru evrilmeye başlamıştır. Özellikle Öcalan'ın çözüm sürecinin kaderini Suriye'deki gelişmelerin belirleyeceğini belirtmesi reelde de bir vaka olarak ortaya çlkmıştır. PYD/YPG'nin Suriye'de etkinliğini arttırması ve Suriye'nin kuzey sınırında önemli bir bölgenin kontrolünü eline geçirmesi ve kantonlar kurması bu süreçte Türkiye açısından potansiyel bir risk olarak görülmeye bașlanmıştır. Suriye'de IŞ̦iD'in de hızla alan hâkimiyetini arttırması Kürtlerle karşı karşıya gelmesine yol açmış ve Kobani'nin işgali süreci gelişmiştir. Bu dönemde 6-7 Ekim Kobani olaylarının ortaya çıkması, çözüm sürecinin karşı karşıya kaldığı önemli bir krizdir.

Halkların Demokratik Partisi (HDP) Merkez Yürütme Kurulu'nun çağrısı üzerine tüm ülke genelinde 6-7 Ekim günlerinde gerçekleșen terör eylemlerinde (Kobani olayları) 33 vatandaş yaşamını yitirmiş̦tir (Anadolu Ajansı, 2015). Kobani olayları aslında çözüm sürecinin güvenlik boyutunun turnusol kâğıdı işlevini açıklamaktadır. Çözüm sürecinde terörle mücadelenin belirli faktörlere bağlı olarak duraklaması, KCK'nın alan hâkimiyetini arttırmasına kapı aralamıștır. Ayrıca heyet görüşmelerinin başladığı süreçte (Şubat 2013) gençlik örgütlenmesinin isim ve yapı değişikliğine giderek YDGH (Yurtsever Devrimci Gençlik Hareketi) adını almasından sonra şehir odaklı eylemler dikkat çekmeye başlamıştır.

Çözüm sürecinin zayıf karnı olan PKK/KCK'nın şehirlerde oluşturduğu silahlı yapılanmanın ilk isyan girişimi denemesi (Kobani olayları) bu süreçte ortaya yeni bir olguyu çıkartmıştır. Bu strateji Öcalan tarafından 2000 sonrasında "Öz Savunma Yaklaşımı" şeklinde ortaya konulmuştur. Öz savunma yaklaşımı sadece silahlı eylemlerin temel referans noktası, toplumsal ya da siyasal meșruiyet kaynağı olarak değil, aynı zamanda çözüm ve görüşme süreçlerinde Öcalan-KCK yapısının sıklıkla dile getirdiği bir tehdit unsurudur. Bu durum 2009 Demokratik Açılım sürecinde Öcalan tarafından "süreç tıkanırsa benim rolüm sona erer, bundan sonra KCK ve öz savunma devreye girer" minvalindeki beyanlarında açıkça görülmüştür. Aynı durumun tekrarı 2013 sonrası 
başlayan Çözüm Sürecinde de yaşanmıștır. Öcalan İmralı heyet görüşmelerinde sıklıkla süreçte tıkanma olursa ya da oyalama taktikleri ön plana çıarsa, öz savunmanın devreye gireceğini ve özerklik stratejisinin demokratik siyaset çözümü yerine öz savunma çözümü temelinde yaşanacağını vurgulamıștır. Örgüt bir yandan legal siyasi söylemlerde bulunurken, öte yandan yeni silahlı aparatlar ve yapılar inşa etmektedir. 2013 yılı bașında başlayan çözüm sürecinden bir ay sonra Komalen Ciwanen Kongresinde gençlik yapısını legal-illegal (Siyasi Parti Gençliği legal-YDGH illegal) olarak ayırmıştır. Örgütün YDGH (Yurtsever Devrimci Gençlik Hareketi) yapılanması Şubat 2013'ten itibaren klasikgençlik örgütlerinden farklı olarak șehir odaklı eylemsellik birimi haline getirilmiștir. Bu durum Çözüm Sürecinin en hararetli olduğu 2013 yazında YDGH yapılanmasının Cizre, Sur, Silopi gibi ilçelerde askeri-polisiye düzen içerisinde içtima yaptıkları ve bunu ileride yaşanacak bir isyan girişiminin öncü denemesi olarak gördüklerini göstermektedir. Ancak bu durumun ciddiyeti süreç içerisinde anlaşılamamıştır. YDGH yapılanması, içtima, tören ve çeşitli üniformalarla propaganda faaliyetlerinin yanında il ve ilçelerde yol kontrolleri, kimlik kontrolleri, trafik ve asayiş uygulamaları gibi alternatif bir kolluk sistemi imajı vermeye çalışmıştır. Özellikle gençlerden oluşan bu ekipler kendilerini KCK ya da YDGH asayiş birimi şeklinde motive etmişlerdir (Haberler, 2015)

Heyet görüşmelerinin son halkası olarak nitelendirilebilecek süreç Kobani olayları sonrası Dolmabahçe Sarayında İmralı heyeti ile hükümet yetkilileri arasında yapılan görüşme odağında şekillenmiştir. Bu görüșmede HDP'li vekiller Öcalan'ın mesajını doğrudan ve kamuoyuna açık şekilde Hükümet yetkililerine iletmişlerdir. Bu gelişme süreç içerisinde, en ağır şekilde eleştirilen konudur. Çözüm sürecinde HDP'nin rolü ağırlıklı olarak iletişim sorumluluğu odağında gelişmiştir. Bu durum Kürtler açısından HDP'nin Kürt sorunundaki statüsünü yansıtması bağlamında dikkat çeken bir durumdur. Bu süreçte HDP, geçmişteki avukat görüşme notlarını aktaran avukatlara benzer bir işlev ifa etmiştir. Kandil ziyaretlerinde KCK'nın sürece ilişkin perspektiflerini İmralı'ya, İmralı'nın yaklaşımlarını ise KCK'ya taşıması, HDP'nin toplumsal tabandaki özgül ağırlığını olumsuz etkileyen bir durum olmuștur.

Dolmabahçe görüşmelerinden (28 Şubat 2015) 7 Haziran seçimlerine kadar çözüm süreci, sadece söylemde kalan, pratikte somut bir yansıması olmayan bir noktaya gerilemiştir. Sonuç olarak KCK, çözüm sürecinden şehir savaşlarına geçerek, HDP'nin siyasal alandaki kabiliyetini kısıtlamış, siyasi bir lider profili olarak Demirtaş'ın etkin pozisyonunu edilgen konuma geriletmiş, Kürt siyaseti ve Türkiyelileşme ümidini taşıyan inşalarda derin bir hayal kırıklığı yaratmış, Doğu ve Güneydoğu'da çözüm süreci ile umutlanan halkın bir kez daha derin bir travma yaşamasına, çatışmalı bir sürecin ortasında kalmasına yol açmıştır. Kürt siyasetinin geleceği açısından büyük bir tahribat oluşmasına yol açan KCK, bu süreçte kendi politik ajandasını şartlar ve konjonktür sebebiyle "demokratik siyaset" ile yürütemeyeceğini ifade ederek "öz yönetim" birimlerini "öz savunma” anlayışıyla hayata geçirmeye çalışmıştır (Aktay, 2016).

Siyasi iktidarın tüm siyasi riskleri göze alarak başlattığı bu süreç, terör örgütünün silah bırakma, şiddetten vazgeçme çabaları yerine şiddeti alevlendirici faaliyetleri nedeniyle sona ermiștir. Karaca'nın (Karaca, 2015) belirttiği gibi "HDP eliyle PKK'nın neden silah bırakmaması gerektiğine ikna edilmiş bir Türk kamuoyu" oluşturma çabaları sürecin akamete uğramasına neden olmuştur. Demokratik Açılım ve Çözüm süreçlerinin genel çerçevesini bu olaylar oluşturmaktadır. Bundan sonraki alt başlıkta bu süreçlerin de facto ve olması gereken durumlar bakımından analitik analizi yapılacaktır.

\section{Süreç Analizleri}

Müzakere süreçlerinin doğası gereği taraflardan bir tanesi terör örgütleri olmak durumundadır ancak başarıya ulaşmak isteniyorsa terör örgütü dışındaki aktörlerinde 
sürece müdahil edilmesi gerekmektedir. IRA ve ETA ile müzakere süreçlerinde başarıyı doğuran ana unsur sürece diğer siyasi aktörlerin ve taraflarında müdahil edilmesidir (Cronin, 2009), (Cronin, 2006), (Özçer, 2006). Müdahillik sorunsalı beraberinde muhataplık problemini doğurmaktadır zira doğru aktör ile doğru meselenin ele alınması kamuoyu desteği açısından oldukça önemlidir. Aksi takdirde süreç devlet açısından beklenenin tam tersi bir etkiye sebep olabilecektir. Çözüm süreçlerinde PKK'nın siyasal sistem üzerindeki etkisini arttırmasının temel sebeplerinden birisi de bu süreçlerde Kürt sorununun temel bileșenleri olarak ele alınan; anadil, kimlik, geçmişte yaşanan travmalar, ekonomik geri kalmışlık ve kültürel haklar gibi konuların legal siyasi partiler ile değil, PKK ve Öcalan ile görüşülmesinden kaynaklanmaktadır. PKK'nın dile getirmesinden sonra Kürt dili veya kültürel haklar ile ilgili olarak adım atılması, ya da atılan pozitif bir adım ile ilgili konularda kamuoyunda PKK'nın muhatap alındığı algısının yaygın olması, doğrudan doğruya örgütün bu kazanımları "zorun rolü" ile elde ettiği söylemini güçlendiren bir sonuç ortaya çıkarmaktadır. Kürt sorununda önemli bir yer işgal eden terör sorunu, öncelikle çözülmesi gereken bir mesele olduğu için PKK ile çeşitli boyutlarda görüșmeler yapılması doğal bir durumdur. Ancak terör sorunu dışındaki konularda PKK ya da Öcalan'ın asli aktör olarak görülmesi, Kürt legal siyasetindeki aktörlerin çözüm süreçlerinde tali ya da edilgen bir konuma gerilemesi sorununu ortaya çıkarmaktadır.

AK Parti'nin Demokratik Açılım konusundaki yayınladığı yol haritasında (AK Parti, 2010, s. 72) muhatabın terör örgütü olmadığı, sorunun toplumsal bir sorun olması hasebiyle muhatabın toplum ve tüm siyasi aktörler olduğu açıkça ve isabetli bir şekilde belirtilmiş olsa dahi süreç bu minvalde devam edememiștir. Tek muhatabın "Öcalan" gibi gösterilmesinde siyasi iktidardan öte medyanın ve muhalefetin etkisi büyük olmuştur. Merkez medyada yazan Mustafa Akyol (Akyol, 2014), Emre Aköz (Aköz, 2015), Fatih Altaylı (Altaylı, 2014) ve sayısını çoğaltabileceğimiz diğer yazarlar tarafından Öcalan; "barışın mimarı", "milli", "terör eylemlerini durduran kişi" olarak nitelendirilmiştir. Cengiz Çandar ise Öcalan'ı, "çözüme gidiş noktasında stratejik bir yönlendirici” olarak betimlemektedir (Kapmaz, 2011, s. 8). Bu nitelemeler süreç içerisinde Öcalan’ı “terörist başı" sıfatından "Kürtlerin önderi" gibi bir konuma getirmiștir. Nitekim sürecin icracılarından olan bir başbakan yardımcısının "beğenseniz de beğenmeseniz de Öcalan Kürtlerin lideridir" (Atalay, 2014) açıklamaları her ne kadar günlük politika açısından uygun gibi görünse dahi uzun soluklu süreç açısından önemli kayıplara neden olmuştur. Ancak burada Kürt siyasilerinin asli irade olarak Öcalan'ı ve PKK'yı işaret etmeleri de önemli bir tıkanmaya yol açmakta, devlet ya da hükümet yetkilileri legal alandaki Kürt siyasilerin edilgen kalmaları sebebiyle Öcalan odaklı hareket etmektedirler.

2009 yılında DTP Grup Başkan Vekili Selahattin Demirtaş (Demirtaş, 2009) “DTP meşru muhatap iken ne diye çözüm için sürekli İmralı'yı işaret ediyor?" șeklindeki soruya, DTP'nin kendisini muhatap olarak görmekte olduğunu ancak DTP'nin silah sorununu çözecek merci olmadığını, PKK'nın DTP'den önce var olduğunu ve Dünyanın her yerinde örgütlü bir sisteminin bulunduğunu belirterek kendilerinin böylesi bir yapı üzerinde etki veya hâkimiyet tesis edebilecek imkânlarının olmadığını ifade etmektedir. Demirtaş'ın bu açıklaması çözüm veya görüşme süreçlerinde DTP ya da legal siyasi oluşumların edilgen pozisyonda kaldıklarını ikrar eden bir yaklaşımdır. Demirtaş’ın PKK üzerinde çözüm anlamında hâkimiyet ya da yönlendirme etkilerinin olmadığını beyan etmesi bu alandaki sorunun bir boyutudur. Bununla beraber, PKK'nın ya da güncel haliyle KCK'nın siyasi parti üzerindeki etkisinin de belirtilmesi gerekmektedir. Bu dönemde DTP'nin PKK üzerinde yapısal bir etkisi olmayacağı bilinmekle beraber, PKK/KCK'nın parti üzerindeki etkisinin varlığl, doğrudan doğruya legal siyasi oluşumların Kürt sorununun şiddet boyutunun çözümünde sahada varlık göstermelerini imkânsız hale getirmektedir. Sonuç olarak Demirtaş'ın açıladığı durum, örgütün çözüm süreçlerinde doğrudan aktör haline 
gelerek siyasal sistemin en önemli tartışma süjesi olan Kürt sorununun doğrudan muhataplığı noktasına evrildiğini göstermektedir.

Medyanın ve muhalefetin yukarıda belirtilen bu tutumunun yanı sıra kimi akademisyenlerde PKK'nın, çözüm sürecinde etkin bir "ulusal aktör" olarak yer almasını önermektedir. Devlet ve "diğer Kürt aktörler" arasındaki sadakat sorunun ancak bu şekilde aşılabileceğini iddia etmektedirler (Bozarslan, 2014, s. 79), (Aktaş, 2014). Çözüm sürecinde PKK'nın söz sahibi olamayacağı kültürel, sosyal konular gibi alanlarda dahi sürece müdahil olma arzusu çözümsüzlüğün nedenlerinden birisi olmuştur.

IRA ve ETA müzakerelerinin getirdiği temel kazanımların altında, Sin Fein ve Herri Batasuna gibi örgüt uzantısı siyasi partiler ile örgütün bağının kesilmesi ve silahlı kanat olmadan, politik yollardan sorunun çözülebileceğine siyasi partilerin inanmıș olması yatmaktadır. Sin Fein'i IRA'dan uzaklaştırmak (Crenshaw, Wilkinson , Alterman, \& Schaffer, 1999, s. 6) ve ETA ile müzakerelerde Herri Batasuna'yı çözüm sürecine dâhil etmek (Özçer, 2006) başarının önemli adımlarındandır. Bununla beraber Türkiye örneğinde siyasi partiler olan HDP-DTP yetkilileri ise süreçte ellerini tașın altına koymak yerine, yukarıda Demirtaş örneğinde belirtildiği gibi devamlı terör örgütünü işaret etmeyi seçmişlerdir. Siyasi partinin bu tercihi, Türkiye örneğindeki kısmı başarısızlığın önemli bir faktörüdür. IRA'nın neredeyse yüz yıllık mücadelesinde kendi tabanı dâhil olmak üzere toplumda destek bulamamasının en önemli nedeni, IRA ile ortak tabandan beslenen siyasi parti Sin Fein'in IRA'nın eylemlerini kınar bir pozisyona gelmesidir. IRA sivillere karşı gerçekleştirdiği şiddet eylemleri nedeniyle zamanla kendi tabanı ve diasporasında dahi yalnız kalmıș ve Sin Fein, IRA'nın eylemlerini kınayan açıklamalarda bulunmuștur. Bu bağlamda IRA'yı bitiren yöntem; yalnızlaștırılmış bir örgütle mücadele iken ETA ile müzakere sürecinde benzer bir yalnızlaștırma sağlanamamıș ve ETA'nın siyasi kolu olan Batasuna Partisi örgütten bağımsız faaliyet yürütememiștir (Alptekin, 2018, s. 69-70). HDP-DTP çizgisindeki siyasilerin çözüm sürecindeki açılamaları- Demirtaş'ın yukarıda belirtilen açıklaması veya Ahmet Türk'ün çözüm için PKK'yı sadece Öcalan'ın etkileyebileceğini söylemesi (Kapmaz, 2011, s. 492) bu durumun bariz bir örneğidirPKK/KCK'nın yalnızlaștırılması ve IRA örneğinde olduğu gibi siyaseten müzakerelerin devam ettirilmesi şeklinde olması gerekirken tam aksine tek muhatap olarak, ABD ve AB terör örgütleri listesine adını yazdıran, PKK/KCK işaret edilmiştir. Bu durum çözüm süreçlerini, çözümsüzlükle sonuçlandıran bir diğer başat faktördür.

Sürecin aktörleri kadar ne zaman başladığı da önem arz etmektedir. Terör örgütleri silahla bir kazanım elde edemeyeceklerini düşündüklerinde yahut bir açmaz içerisine girdiklerinde diyalog masasına ön koşulsuz otururlar (Byman, 2006, s. 409). Nitekim 1999 yılında Öcalan, PKK'ya yazdığı mektupta; devletle eșit statüde olmadıklarını bu durumun normal olduğunu ve önce örgütün adım atmak suretiyle adamlarını sınır dışına çekmesi gerektiğini söylemektedir. Ayrıca açıkça "şu çok iyi bilinmeli ki elde silah her gün eylem yapan gücü devlet muhatap kabul etmez" ifadesini kullanmaktadır (Kapmaz, 2011, s. 88; 99-100). Demokratik Açılım ve çözüm Süreçlerinin başlarında da benzer ifadeleri kullanan Öcalan, 7 Haziran seçimleri sonrası tüm bu söylemlerin ötesinde muhatap alınmanın verdiği "gururla" hareket eder hale gelmiş ve kendisini devletin karşısında bir taraf olarak görmüștür. Sürecin başlama zamanı doğru olmakla beraber süreç içerisinde KCK'nın etkinliğini bir şekilde sürdürebilmesi beraberinde diyaloggüvenlik dengesini bozmuștur. İstenilen neticeye ulașılamamasındaki bir diğer faktör ise, zamanlama açısından başlangıç noktasında devletin, sahip olduğu avantajı süreç içerisinde kısmen de olsa yitirmesidir.

Başarı ile sonuçlanan müzakereleri incelediğimizde sürecin kiminle, ne zaman yürütüldüğü kadar sürecin nasıl yönetildiği de dikkat çekmektedir. Zira bir tarafın devlet olduğu çözüm süreçlerinde karşı tarafta birden çok aktör söz konusudur. ETA ile yapılan görüşmelerde silah bırakma, sınır dıșına çekilme, eylemsizlik gibi teknik konular ETA ile 
görüşülmüş; siyasi-politik konular ise Batasuna ve PSE gibi siyasi partilerle görüşülmüştür (Whitfield, 2015, s. 8). Sayın Erdoğan' da bu noktada doğru bir yaklaşım sergilemek suretiyle "biz terörle mücadele, siyasi iradeyle de müzakere ederiz" mesajını vermiştir (Erdoğan R. T., 2011). Bu anlayıș reel duruma yansitılamamış ve bir anlamda konunun tek tarafı Öcalan (KCK bașkanı) olmuştur zira süreç içerisinde teknik konuların ötesinde siyasi konularında Öcalan ile görüşüldüğü açık kaynaklara yansımıştır (Kapmaz, 2011), (Durukan, t.y). Mecliste kurulacak komisyonlardan, yapılacak olan yeni anayasanın içeriğine varan görüşmelerin olduğu, daha da ileri gitmek suretiyle PKK'nın şikâyetçi olduğu vali ve emniyet müdürlerinin tespit edilip kendilerine şikâyet edilmesi durumunda gereğinin yapılacağı devlet yetkililerince KCK üst yönetimine vaat edildiği iddia edilmektedir (Güller, 2015, s. 139-141;109). Oysaki görüşme sistematiği içerisinde devleti temsil eden tarafın devlet görevlilerini zora sokacak bu tür söylemlerde bulunmaları, çözüm odaklı görüşme stratejisi bağlamında kabul edilemez bir olgudur. Bununla beraber bu görevliler eğer Perinçek'in iddia ettiği șekilde Ergenekon ve Balyoz soruşturmaları ile cezalandırıldı ise olay içerisinden çıkılmaz bir hal almıştır (Perinçek, 2011). Özellikle Dolmabahçe mutabakatında Öcalan'ın mesajının basına açıklanması ve bu mesaj içerisinde silahların bırakılması hariç hemen hemen her konunun (demokratik cumhuriyet, kadın, kültür, ekolojik sorunlar) bulunması sürecin açmazlarından birisidir.

Çözüm sürecinde Türkiye tarihinde daha önceden denenmemiş fakat fikrî anlamda bir o kadar da isabetli olan "akil insanlar" heyeti oluşturulmuştur. Bu heyet; sanat camiasından, iş dünyasına ve akademisyenlere kadar geniş bir yelpazede teșekkül edilmiștir. IRA ve ETA müzakerelerinde sivil toplum örgütlerinin ve rahiplerin fonksiyonunu üstlenen (Powell, 2015), (Doucet, 2017) bu yapı, halka nüfuz etmek suretiyle sürecin ne olduğunu ve ne olmadığını izah ederek bir anlamda halkın nabzını tutma ve halktan gelecek tepkileri ölçmek için oluşturulmuştur. IRA, ETA ve FARC örneklerine baktığımızda bu tür görüşmeler genel olarak istihbarat örgütleri tarafından halktan gizli başlatılmakta ve yürütülmektedir (Schmitt, 2009), (Powell, 2015). Süreç belirli bir olgunluğa eriştikten sonra kamuoyu ile paylaşılmaktadır. Kamuoyunun sahip olduğu bilgiye göre vereceği tepki hesap edilmek suretiyle atılacak olan yeni adımlar planlanmaktadır (Guelke, 2008, s. 68). Bir anlamda akil insanlar heyeti kamuoyunu bilgilendirmek ve önceden hazırlamak için kullanılabilecek bir argümandır. Bu anlamda Türkiye örneğinde akil insanlar heyeti, geçmiş tecrübelerden farklı olarak, süreçle birden bire yüzleșen kamuoyunun nabzını ölçmek ve bilgi paylaşımında bulunmak durumda kalmıştır. Bu nedenledir ki fikri anlamdaki var olma sebebi olan kamuoyunu hazırlama misyonunu tam anlamıyla gerçekleştirememiştir.

Müzakerelerin yürütülmesi sürecinde son olarak silahların bırakılması konusuna değinmek gerekmektedir. Zira diyalog ancak şiddetten vazgeçen-vazgeçmeye niyetli olanlar ile mümkün olabilecektir (Whitfield, 2015, s. 5). Silahları bırakma konusu politik etkileri yanında psikolojik etkileri de olan bir husustur. IRA ile müzakere süreçlerinde IRA'nın silah bırakmaya ikna edilmesi zor olmuştur zira IRA yapılacak görüşmelerden kendi istediği sonucun çıkmaması durumunda tekrardan silahlı eylemlere dönmeyi planlamaktadır (Crenshaw, Wilkinson, Alterman, \& Schaffer, 1999, s. 6). Benzer bir süreç Türkiye örneğinde yaşanmıştır. Çözüm süreçleri devam ederken, örgütün askeri kanat sorumlusu olan Karayılan, New York Times'a verdiği röportajda silah bırakmak gibi bir durumun söz konusu olmadığını belirtmektedir (Karayılan, 2013). Oysaki terör örgütünün üst düzey yöneticilerinden olan bu ismin diyalog sürecinin sağlıklı devam edebilmesi için devletin ön koşul olarak şiddet eylemlerinin kesilmesini ve silahsızlanmanın sağlanmasını istediğini bilmemesi söz konusu olamaz. Bu örnek terör örgütünün müzakereler sırasında ortaya koyduğu ikircikli tavrı gözler önüne sermektedir. Zira siyasi iktidar ciddi siyasi riskler almak suretiyle Türkiye'nin geleceği 
açısından en önemli sorun olarak görülen konuda demokrasi adına adımlar atmaya çalışırken, terör örgütü kendi payına düşeni söylem olarak dahi yerine getirmemiştir.

SWOT analizi tablosunda belirtilen müzakerelerin güçlü yönleri ve doğuracağı fırsatlar bakımından bir değerlendirme yapmak gerekirse Türkiye'de gerçekleșen Demokratik Açlım ve Çözüm Süreçlerinin en büyük kazanımı; devletin terör örgütünün gizli ajandasını açı̆̆a çıkartmak suretiyle radikallerin yalnızlaşmasını sağlamasıdır. Nitekim süreçle ilgili yapılan bir alan araştırmasında sürecin kimin tarafından çözüleceği sorusuna verilen yanıtlarda AKP ve BDP işaret edilmiştir. Öcalan ve PKK'nın popülaritesi ise oldukça düşüktür (KONDA, 2011, s. 136-140). Sürecin Türkiye coğrafyasında, şiddetin biteceği yönünde bir beklenti yarattığı ve SWOT tablosunda belirtildiği gibi bazı fırsatlar doğurduğu Akil İnsanlara yöneltilen "30 yıldır bekliyoruz neden bu kadar geç kaldınız? keşke daha önce gelseydiniz" meyandaki ifadelerden anlaşılmaktadır (Oran, 2014, s. 41). Diğer taraftan müzakerelerin zayıf yönü ve yarattığı-yaratacağı tehditler bakımından akim kalan sürecin örgüt tarafından nasıl kullanıldığı ile ilgili verilere, örneğin örgütün eleman sayısındaki ve lojistik kapasitendeki artış-azalış gibi, bilimsel sınırlılıklardan dolayı ulaşmak mümkün değildir. Şiddet kullanılmadan bir sonuca ulaşılamayacağı fikrinin yaygınlaşması tehdidi ve bu tehdidin bertaraf edilmesiyle ilgili öneriler Akil İnsanlar Heyetinin Güneydoğu raporunda irdelenmiștir.

\section{Sonuç ve Değerlendirme}

Çözüm süreçleri-müzakere (diyalog) süreçleri; kendi içerisinde barındırdıkları tehditlerin yanı sıra siyasi iktidarlar açısından da ciddi riskler taşıyan süreçlerdir. Türkiye örneğinde ele aldığımız Demokratik Açlım ve Çözüm Süreçlerinin kendi içerisinde taşıdıkları en büyük tehdit terör örgütünün meşrulaşabilecek olmasıydı. 1999 yılında hükümet yetkilileri ile masaya oturan FARC örgütü, kendi ideolojilerini ve mesajlarını iletebilmek adına her türlü imkâna sahip olmuşlardır. Devletin sunduğu her türlü imkâna ve açtığı diyalog kanallarına rağmen şiddet eylemlerine geri dönen FARC, kendi tabanından dahi eskisi gibi destek görmeyerek, halkın çoğunluğunca narko-terörist suç örgütü olarak tanımlanmaya başlamış ve zamanla gördüğü destek azalmıştır (Powell, 2015, s. 4). Tüm siyasi riskleri alarak bu ișe başlayan AK Parti hükümeti, her ne kadar muhalefet tarafından yalnız bırakılmış olsa ve her ne kadar süreç nihayete erdirilememiş olsa dahi, PKK/KCK konusunda benzer bir başarıyı sağlamıştır. Zira 2018 yılında terör örgütüne Türkiye'den katılım sayısı geçtiğimiz son otuz yılın en düşük seviyesindedir. İç ișleri bakanlığı resmi verilerine göre bu sayı 2015 yılında 3 bin 881 iken 2018 yılında 95'e düşmüștür (Soylu, 2018). Elbette ki bu durumun harici birçok faktörü söz konusu olmakla beraber, çözüm süreçlerinde terör örgütünün sergilediği ikircikli tavrın kendi tabanınca görülmesi de etkili olmuștur. Zira KCK sisteminde çözüm süreçleri mutlak legal siyasete geçiş anlamıyla değil, dikotomik bir perspektif ile değerlendirilmektedir. Somut bir örnek vermek gerekirse, örgüt bir yandan legal siyasi söylemlerde bulunurken öte yandan yeni silahlı aparatlar ve yapılar (YDGH) inşa etmiştir.

Çözüm süreçlerinde gerçekleşen olaylardan en çok eleştiri alan Habur geçişleri olmuştur. Zira Habur geçişleri planlandığı gibi bir "teslim olma, eve dönüş" olgusundan daha çok terör örgütünün propaganda faaliyeti haline gelmiştir. Özel yetkili hâkim ve savcıların yargılama yapmak amacıyla Habur'a götürülmesi sürecin açmazlarından bir tanesidir. Oysaki Türkiye örneğinde, 1999 tarihli 4450 sayılı bir pişmanlık yasası söz konusudur. Bu yasa çağdaş hukuk sistemlerine daha uygun olup eyleme katılmama, silah bırakma, itiraflarıyla suç işlenmesine engel olma gibi daha somut gerekçelerle cezasızlık sebeplerini düzenlemişti. Türkiye'nin geçmiş örneklerinde 4450 sayılı bir yasa ve uygulaması örneği varken, geçmiş uygulamalardan ders çıkartmadan atılan yeni adımlar Habur örneğinde olduğu gibi toplumda infiale neden olabilmektedir. 
Çözüm süreçleri "milli süreçler, milli meseleler" olduklarından dolayı, sorunun çözümüne iktidar-muhalefet tüm siyasi partilerin katkıda bulunması hayati önem arz etmektedir. Nitekim ETA ile yapılan ve başarıya ulaşan müzakere sürecinde, İspanyol hükümeti şiddeti savunan ve terör örgütü ile organik bağı olan partiler hariç tüm siyasi partilerin desteğini almaya çalıșmıștır. Hükümetin bu çabaları muhalif siyasi kimlikler tarafından "terör örgütü ile anlaşma yapılıyor" söylemi ile de yıpratılmamıștır (Şimşek, 2009, s. 278). Tüm bu demokratik çabaların yanı sıra İspanya mahkemeleri, müzakere sürecinde terör örgütleriyle organik bağı olan ve şiddeti savunan partileri merkezi hükümetin çıkarttığı siyasi partiler kanunu çerçevesinde kapatmıştır. Şiddeti savunmak ve terör örgütü ile organik bağı bulunma haricinde en aşırı bölünme fikrini savunan siyasi partilere dahi dokunulmamıştır. Şiddeti savunan, öven ve terör örgütü ile organik bağı bulunan siyasi partilerin kapatılmasının insan hakkı ihlali oluşturmadığı ise AİHM vermiş olduğu kararlar ile tescillenmiștir (UTSAM, 2010). Türkiye örneğinde ise benzer bir süreç işletilememiştir. Zira süreç devam ederken dahi kimi siyasi partiler şiddet veya terör örgütü minvalinde açıklamalarda bulunmuş ve bu açıklamalar yaptırımsız bırakılmıştır.

Habur örneğinde bir kez daha görüleceği üzere çözüm süreçleri hassas süreçler olup, geçmişin tecrübeleri ışığında geleceğe adım atmayı gerektiren süreçlerdir. Son iki süreçle ilgili olarak yalnız Öcalan'ın muhatap alınması, toplumsal desteğin tam anlamıyla sağlanamaması, muhalefetin siyasi nedenlerle iktidardan desteğini esirgemesi ve Sayın Cumhurbaşkanının bazı aşamalardan habersiz olması çözümsüzlüğe neden olmuştur. Tarihsel örnekler terör örgütleriyle görüşmelerin bir yere kadar yapıldığını, başarılı olan süreçlerde, bu aşamadan sonra terör örgütünün siyasi kanadı olan partinin görüşmelere dâhil olduğunu göstermektedir. Görüşmeler belirli bir aşamaya geldikten sonra, toplum her şeyden önce fikri olarak çözüm sürecine hazırlanmalıdır. AK Parti'nin çıkarmış olduğu broşür (AK Parti, 2010) bu görevi büyük ölçüde ifa etmekle beraber toplumun her katmanına hitap edebilecek daha görsel ve sosyal çalışmalarla hazırlık süreci desteklenmelidir. Çözüm süreçleri, hükümetlerin ellerini taşın altına koydukları ancak gerçek anlamda devlet meseleleridirler. Bu nedenledir ki muhalefetin bu süreçleri, siyasi rant uğruna kullanmamaları gerekmektedir. Muhalefet desteği, toplumsal mutabakatın sağlanmasında da önem arz etmektedir. Ancak Türkiye örneğinde muhalefet partileri bu sürece sahip çıkmamışlardır. Daha da ileri gitmek suretiyle "hainlik" ile itham eden açıklamalarda bulunmuşlardır (AK Parti, 2010, s. 82-94). Çözüm süreçleri güçlü liderlerin ellerinde çözüme ulaşabilecek olan süreçlerdir. Bu anlamda Türkiye örneğinde Sayın Erdoğan bu sorumluluğu üstlenmiş olmakla beraber Dolmabahçe mutabakatından duyduğu rahatsızlık, süreç içerisinde bilgisiz bırakıldığı yahut bazı bürokratların kendisinden habersiz faaliyetlerde bulunduğu sorununu akıllara getirmektedir (Erdem, 2016, s. 23).

SWOT analizi tablosu göstermektedir ki; terörizmle mücadelede doğru bir şekilde uygulanan müzakere tekniğinin güçlü yanları ve doğuracağı firsatlar, zayıf yönleri ve oluşturacağı tehditlerden çok daha fazladır. Doğası gereği müzakerenin taraflarından bir tanesi terör örgütleridir ancak başarıya ulaşmış örnekler göstermektedir ki; terör örgütleriyle sadece teknik konularda sınırlı bir çerçevede müzakere edilmelidir. Müzakerelerin diğer konuları toplumsal aktörlerin geniş katılımı ile gerçekleștirilmelidir. Türkiye örneğinde toplumsal aktörlerin geniş katılımının sağlanması ve terör örgütüyle sadece kısıtlı alanlarda müzakere edilmesi konularında kısmi başarı sağlanmıştır.

Zamanlama bakımından Türkiye örneğindeki müzakerelerin, örgütün silahlı eylemler ile başarıyı sağlayamayacağını düșündüğü bir dönemde bașlamıș olması doğru bir adım olmakla beraber; süreç içerisinde belirlenen yol haritalarında somut adımların net bir şekilde ortaya konulması ve hayata geçirilmesindeki başarısızlıklar çözümü akamete uğratan etkenlerdendir. Yıldız'ın (2014, s. 302-303) da belirttiği gibi müzakereler diyalog aşamasında kalmış yasal ve somut adımlar atılmamıştır. 
Müzakerelerin yürütülmesinde yasal adımların önemi aşikârdır. Çözüm ve Demokratik Açılım süreçlerinde kısmi yasal düzenlemeler yapılmakla beraber kilit taşı pozisyonundaki alanlarla ilgili net yasal düzenlemeler söz konusu olmamıștır. Müzakere süreçlerinde iktidar partisinin muhalefet cephesince yalnız bırakılması ve yapılacak olan reformlar bakımından muhalefetin elini taşın altına koymaması, yasal düzenlemeler konusunda yaşanan açmazın etkenlerindendir. Son olarak ifade etmek gerekir ki; toplumsal mutabakatın sağlanması ve daha geniş halk kitlesinin desteğinin alınması bakımından müzakere süreci halka yeterince iyi açıklan(a)mamıș, kapalı kapı müzakere süreci tercih edilmiştir. Sürecin akamete uğramasının bir nedeni de bu tercihtir. Zira belirli bir olgunluğa erişen müzakere süreçlerinin artık şeffaflık kazanması halk desteğinin sağlanması açısından oldukça önemlidir. Başarılı olan süreçler göstermektedir ki, çözüm süreçleri rasyonel araçlarla kiminle, ne zaman, nasıl müzakere sorularına verilecek doğru cevaplarla, geçmişin ışı̆̆ı ile geleceğe bakmak suretiyle nihayete erdirilebilmektedirler.

\section{KAYNAKÇA}

AK Parti. (2010). Soruları ve Cevaplarıyla Demokratik Açılım Süreci Milli Birlik ve Kardeşlik Projesi. Ankara: AK Parti Tanıtım ve Medya Başkanlığı.

AKÖZ, E. (2015, Aralık 03). Sabah Gazetesi. Kasım 2018 tarihinde Sabah Gazetesi: https://www.sabah.com.tr/yazarlar/akoz/2015/12/03/ocalan-milli-pkk-bolgesel adresinden alındı

AKTAY, Y. (2016, Şubat 26). Kürtlerin Hakkı Hendek Siyaseti Olamaz. SDE: http://www.sde.org.tr/tr/newsdetail/kurtlerin-hakki-hendek-siyaseti-olamaz/4494 adresinden alındı BILGESAM.

AKYÜREK, S. (2011). Demokratik Açılım ve Toplumsal Algılar. İstanbul:

AKYOL, M. (2014, Şubat 18). Hür Fikirler. Kasım 2018 tarihinde Hür Fikirler Web Sitesi: http://www.hurfikirler.com/iyi-ki-ocalan-var-3/ adresinden alındı

ALPTEKIN, H. (2018). Etnik Terör ve Terörle Mücadele Startejileri: IRA ETA TAMIL KAPLANLARI ve PKK. İstanbul : Seta Vakfi Yayınları.

ALTAYLI, F. (2014, Ekim 24). Öcalan'ı Görünce Sakın Şaşırma. Kasım 2018 tarihinde HaberTürk: https://www.haberturk.com/yazarlar/fatih-altayli1001/1002715-ocalani-gorunce-sakin-sasirma adresinden alındı

Anadolu Ajansı. (2015). Kasim 2018 tarihinde https://www.aa.com.tr/: https://www.aa.com.tr/tr/turkiye/6-7-ekim-olaylarinin-bilancosu/436002 adresinden alındı

ATALAY, B. (2014, Ocak 15). Atalay: Öcalan Kürtlerin Lideri. Kasım 2018 tarihinde Cumhuriyet Gazetesi:

http://www.cumhuriyet.com.tr/haber/turkiye/29499/Atalay_Ocalan_Kurtlerin_lideri. html adresinden alındl

BAL, İ. (2006). Alacakaranlıkta Terörle Mücadele ve komplo Teorileri. Ankara: USAK Yayınları.

BAPAT, N. A. (2005). Insurgency and the Opening of Peace Processes. Peace Research, 42(6), 669-717.

BARKEY, K. (2011). Eşklyalar ve Devlet Osmanlı Tarzı Devlet Merkezileşmesi. (Z. Altok, Çev.) İstanbul: Tarih Vakfı Yurt Yayınları. 
BOOKCHIN, M. (1990). The Meaning of Confederalism. Green Perspectives \#20: https://theanarchistlibrary.org/library/murray-bookchin-the-meaning-ofconfederalism adresinden alındı

BOZARSLAN, H. (2014). Türkiye'de 2010'larda Kürt Meselesi . M. Aktaş içinde, Çatışma Çözümleri ve Barış (s. 69-80). İstanbul: İletişim Yayınları.

BYMAN, D. (2006). The Decision to Begin Talks with Terrorists: Lessons for Policymakers. Studies in Conflict \& Terrorism, 29(5), 403-414.

CAŞıN, M. H. (2007). Uluslararası Terörizm. İstanbul: Nobel Yayınları.

CLARK, R. P. (1990). Negotiating with ETA: Obstacles to Peace in the Basque Country. Reno: Reno University Press.

CNNTürk. (2016, 07 11). CNNTürk. Ekim 2018 tarihinde CNNTürk Web Sitesi: https://www.cnnturk.com/fotogaleri/turkiye/baslangictan-bugune-gun-gun-cozumsureci adresinden alındı

COACKLEY, J. (2003). Ethnic Conflict and its Resolution: The Northern Ireland Model. Nationalism and Ethnic Politics, 9(3), 25-34.

CRENSHAW, M., Wilkinson, P., Alterman, J., \& Schaffer, T. (1999). How Terrorism Ends. Institue of Peace. Washington DC: United States Institue of Peace.

CRONIN, A. K. (2006). How al-Qaida Ends. International Security Studies, 31(1), 748.

CRONIN, A. K. (2009). How Terrorism Ends. Princeston: Princeston University. CRONIN, A. K. (2010). When Should We Talk to Terrorist. Washington DC: United States Institue of Peace.

ÇANDAR, C. (2011). Dağdan İniş - PKK Nasıl Silah Bırakır? Kürt Sorunu'nun Şiddetten Arındırılması. Türkiye Ekonomik ve Sosyal Etüdler Vakfi. İstanbul: TESEV.

DEMIRTAŞ, S. (2009, Ekim 13). DTP Grup başkanvekili Demirtaş Kürt Açılımını Değerlendirdi. Ekim 2018 tarihinde www.nasname.com: https://nasname.com/dtpgrup-baskanvekili-selahattin-demirtas-kurt-acilimini-degerlendirdi/ adresinden alındı DOUCET, L. (2017, Nisan 10). ETA'nın 58 yıllık silahlı mücadelesi nasıl bitti?

BBCNews: https://www.bbc.com/turkce/haberler-dunya-39552589 adresinden alındı DURUKAN, N. (t.y). İște Imralı'daki Görüşmenin Tutanakları. Ekim 2018 tarihinde Özelbüroistihbarat:

http://www.ozelburoistihbarat.com/Content/images/archieve/terorle-mucadeledosyasi-imrali-gorusme-tutanaklari-ea3cba5f-5666-4c34-8392-14e2a16870af.pdf adresinden alındı

ERDEM, T. (2016, Ocak). Kendi Tarzında Bir Aşk-ı Memnu (Çözüm Süreci)

Üzerinden 2015 Türkiye'si. Türk Yurdu Dergisi(341), s. 22-26.

ERDOĞAN, İ. (2013). Terörle Mücadele Stratejileri Bağlamında Müzakere:

Türkiye Örneği. Akademik İncelemeler Dergisi, 8(2), 347-392.

ERDOĞAN, R. T. (2011, Eylül 26). Terörle Müzadele, Siyasetle Müzakere. Kasım

2018 tarihinde Radikal Gazetesi: http://www.radikal.com.tr/politika/terorle-mucadelesiyasetle-muzakere-1064437/ adresinden alındı

GÜLER, N. M. (2010). KCK Dosyası: Küresel Devlet Devletsiz Kürtler. İstanbul:

Belge Yayınları.

GÜLLER, M. A. (2015). Hükümet PKK Görüşmeleri 1986-2011. İstanbul: Kaynak Yayınları.

GÜNEŞ, M. E. (2018). Terör Örgütü Olarak PKK'nın Siyasallaşmasında KCK'nın

Rolü. Yayınlanmamış Doktora Tezi. Ankara: Gazi Üniversitesi Sosyal Bilimler Enstitüsü.

GUELKE, A. (2008). Negotiations and Peace Processes. J. Darby, \& R. M. Ginty

içinde, Contemporary Peacemaking (s. 63-77). London: Palgrave Macmillan. 
Haberler. (2015). Kasım 2018 tarihinde www.haberler.com:

https://www.haberler.com/pkk-ydg-h-yi-polis-gucu-olarak-kullaniyor-6831297haberi/ adresinden alındı

HELD, D. (2006). Models of Democracy. Cambridge: Polity Press.

JONES, O. E. (2017). Negotiating with 'New' Terrorists. Strife Journal(7), 22-30.

JONES, S. G., \& Libicki, M. C. (2008). How Terrorist Groups End: Lessons for Counterin Al-Qaida. Santa Monica: RAND Corporation.

KAPMAZ, C. (2011). Öcalan'ın Imralı Günleri. İstanbul: İthaki Yayınları .

KARACA, N. B. (2015, Temmuz 29). Çözüm Süreci Nasıl Bozuldu. Ekim 2018 tarihinde HaberTürk: https://www.haberturk.com/yazarlar/nihal-bengisukaraca/1108603-cozum-sureci-nasil-bozuldu\# adresinden alındı

KARAYILAN, M. (2009, Mayıs 5). Karayılan: Barıș Umudumuz Var- Kuzey Irak Notları. (H. Cemal, Röportaj Yapan) http://www.milliyet.com.tr/baris-umudumuzvar/hasan-cemal/siyaset/siyasetyazardetay/05.05.2009/1090963/default.htm.

KARAYILAN, M. (2013, Nisan 11). Rebel Keeps Kurds' Guns Close at Hand in Peace Talks With Turkey. (T. Arango, Röportaj Yapan) https://www.nytimes.com/2013/04/12/world/middleeast/rebel-kurd-karayilandefiant-in-turkish-talks.html?pagewanted=all.

KHAN, R. M. (2013). Negotiations with TTP: An Analysis of Counter Terrorism Strategy. NDU Journal, 27, 65-92.

KONDA. (2011). Kürt Meselesin'de Algı ve Beklentiler Araştırması . İstanbul .

KURTILLA, M., Mauno, P., Kangas, J., \& Kajanus, M. (2000). Utilizing the Analytic Hierarchy Process (AHP) in SWOT Analysis-A Hybrid Method and Its Application to a Forestcertification Case. Forest Policy and Economics, 1(1), 41-52.

MARTINEZ-HERRERA, E. (2008). Taming Basque Nationalist Extremism? The role of Democratisation, Self-Rule, Reinsertion and Negotiation (1979-2007). Madrid, İspanya.

NEUMANN, P. R. (2007). Negotiating with Terrorists. Foreign Affairs, 8(1), 128138.

ORAN, B. (2014). Kürt Barıșında Batı Cephesi: Ben Ege'de Akilken... İstanbul : İletişim Yayınları.

ÖCALAN, A. (2011). Türkiye'de Demokratikleșme Sorunları Kürdistan'da Çözüm Modelleri (Yol Haritası). Abdullah Öcalan Sosyal Bilimler Akademisi Yayınları. Publishing.

ÖCALAN, A. (2015a). Democratic Confederalism. Honolulu: Transmedia

ÖCALAN, A. (2015b). Demokratik Kurtuluş ve Özgür Yaşamı İnşa (İmralı Notları). Köln: Weşanen Mezopotamya Yayınları.

ÖZÇER, A. (2006). Çoğul İspanya: Anayasal Sistemi ve Ayrılıkçı Terörle Mücadele Modeli. Ankara: İmge Kitapevi.

PERINÇEK, D. (2011, Eylül 16). Görüşme Kaydının İspatladığı Olgular. Ekim 2018 tarihinde http://vatanpartisi.org: http://vatanpartisi.org.tr/genel-merkez/rotayazilari/dogu-perincek-gorusme-kayitlarinin-ispatladigi-olgular-22949 adresinden alındı

PILLAR, P. R. (2001). Terrorism and US Foreign Policy. Washington DC: Brookings Institution Press.

POWELL, J. (2015, Nisan 23). Negotiating with Terrorists. Chatham House: https://www.chathamhouse.org/sites/default/files/field/field_document/20150423\% 20Negotiating\%20with\%20Terrorists.pdf adresinden alındı

RICHARDSON, L. (2006). What Terrorists Want? Understanding the Terrorist Threat. London: John Murray. 
SCHMITT, G. J. (2009, Ağustos 17). Talking to Terrorists: How and When. American Enterprise Institute: http://www.aei.org/publication/talking-to-terroristshow-and-when/ adresinden alındı

SOYLU, S. (2018, Kasım 15). Terör Örgütüne Katılım Son 30 Yılın En Düşük Seviyesinde. Kasım 2018 tarihinde HAberler.com: https://www.haberler.com/terororgutune-katilim-son-30-yilin-en-dusuk-11439785-haberi/ adresinden alındı

STEINBERG, A. (2015). To Negotiate or Not to Negotiate, That is the Question: A Cost Analysis of a Non-Negotiation Policy. Journal of Peace, Conflict \& Development(21), 85-114.

ŞİMŞEK, Y. (2009). İspanya'nın Terörle Mücadelesinde ETA Örneği. İ. Bal, \& S. Özeren içinde, Uzakdoğudan Yeni Kitaya Terörle Mücadele (s. 243-285). Ankara: USAK Yayınları.

UTSAM. (2010). İspanya'nın Terörle Mücadelesi. Ankara: Polis Akademisi Yayınları.

WHITFIELD, T. (2015). The Basque Conflict and ETA. United States Institute of Peace. Washington DC: United States Institute of Peace.

YILDIZ, K. (2014). Çözüm ve Dönüșüm Süreçlerine İlișkin Teorik ve Pratik Yaklaşımlar. M. Aktaş içinde, Çatışma Çözümleri ve Barış (s. 269-307). İstanbul : İletişim Yayınları. 6-13.

YILMAZ, S. (2012). PKK Terör Örgütü ve KCK'da Son Durum. TURAN-SAM, 4(15),

ZART MAN, I. W. (2003). Negotiating with Terrorist. International Negotiation, $8(3), 443-450$.

\section{Summary}

In the history of the fight against terrorism, there is a shift in military-police measures towards pre-emption with socio-economic measures and negotiation. In the past 60 years, Turkey has been struggling intensively with terrorist organizations and especially with the ethnic-separatist terrorist organization. During this struggle, negotiation-solution process-dialogue techniques were also tried. The most serious and closest of these processes is the Democratic opening and resolution processes. The solution processes require a strong leader and government because of their nature that the AK Party governments have had this opportunity. AK Party governments have taken steps to resolve this issue, which is an important issue in terms of Turkish history. In this article, comparative analyses were made by comparing the solution processes in Turkey with the IRA and ETA, which are the successful examples of the negotiations in the fight against ethnic terrorism in the world.

As can be seen in the examples of the world, the states negotiate with terrorist organizations openly or in a confidental manner. The purpose of these negotiations is to draw terrorist organizations from their desires towards their destinies. This process is an academic and practical process. In this article, the academic literature is examined by the answers to the question of who, when and how to negotiate. the result from this review is templated by SWOT technique. Taking into account the threats and opportunities; the strong and weak sides of the negotiations, the process of solution has been analyzed through historical examples. Because the experience on Earth has a guiding role. Our knowledge of the solution processes that take place in the presence of history is limited by open sources. Although we cannot access the whole process due to reasons such as state security, intelligence concerns historical analysis in the light of the available data is made comparatively. The PKK, which evolved into the KCK, is the first part of this three-part work. 
I gave information about the KCK because it is due to the fact that it is the counterpart of the state during the solution process. In the second part, SWOT analysis of the negotiation with terrorist organizations was made and information about the Democratic openingsolution processes were given. In the third part, comparative analysis is presented. The aim of this study is not to criticize the solution processes but to learn from the solution processes for future. According to the findings of the study, the biggest reason for the failure of the solution process in Turkey is that Öcalan is the addressee only. Another reason is the errors caused by the management of the process. Habur events can be an example of this situation. The lack of support by the opposition parties has caused negative consequences. beyond all this, there are educational aspects of the process for Turkey. these lessons from Process Analysis will be instrumental in taking further steps in the future. 